\title{
分散染料によるポリエチレンテレフタレート繊維の 染色における染着領域量の推定
}

\author{
帝人 K K 㵶維加工研究所 喜多村一夫・松 井 健 \\ 京都大学工学部合成化学科 吉 田 善一
}

\section{THE ESTIMATION OF THE AMOUNT OF THE ABSORPTION REGION FOR DISPERSE DYES IN POLYETHYLENE TEREPHTHALATE FIBRE}

\author{
By Kazuo Kitamura*, Taheshi Matsui* and Zen-ichi Yoshida** \\ *(Fibre and Textile Research Institute, Teijin Ltd,, Ibaraki City, Osaka, Japan) \\ **(Department of Synthetic Chemistry, Faculty of Engineering, \\ Kyoto University, Sakyo-kw Kyoto Japan)
}

\begin{abstract}
The weight fraction of polyethylene terephthalate (PET) fibres available for the absorption of disperse dyes was estimated. The fibres used were a commercial brand of staple fibre of PET (regular Tetoron), and a more dyeable one (Tetron T-89, Teijin Ltd.). The apparent solubilities ( $\mathrm{mg}$ dye/g fibre) of the three azo dyes and the contractions in the dyeing process were determined at $100^{\circ} \mathrm{C}, 110^{\circ} \mathrm{C}, 120^{\circ} \mathrm{C}$ and $130^{\circ} \mathrm{C}$, on the fibres. The absorption isotherms of phenol and the contractions accompanying the absorption were also determined at $70^{\circ} \mathrm{C}$. The contractions in the dyeing process depended only on the dyeing temperature for both fibres. The contractions and the apparent solubilities at each dyeing temperature and the contractions and phenol absorbed at the same phenol concentration were much higher for T-89 than for the regular Tetoron.

The weight fraction of polymer available for the absorption of phenol was estimated from the concentrations, at which the same contraction was observed for the dyeing at each temperature, using the method descrived in the previous paper. It is reasonably assumed that this value is equal to the weight fraction of the polymer available for the absorption of dyes. The true solubilities were calculated by dividing the apparent solbilities by the coresponding weight fraction. For the three dyes, the same values were obtained for the true solubilities of these fibres. This indicates the validity of the estimation of dye absorption region.

In the estimation of dye absorption region mentioned above, it is assumed that the contraction in the dyeing process is caused by the same mechanism as for the absorption of phenol. The mechanism of the contraction, in relation to the fine structure, is also discussed in detail.
\end{abstract}

(Received October 6, 1970)

\section{1. 緒} 言

分散染料による眯水性織襍の染色では，標準親和力は 次式であらわされる1。

$$
-\Delta \mu^{\circ}=R T \ln \frac{\left[D_{f}\right]}{\left[D_{s}\right]} \cdot \frac{1}{V}
$$

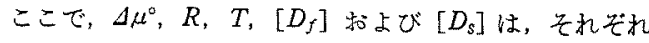
標準漞和力, ガス定数，絶対温度括よび平衡時におけ る，蟣維中特よび染浴中の染料濃度であり，Vは染着有
効容積である。

トリアセテート䋐維の染色では，結晶化度から染着有 効容積を算出し, さらに, 線膨張係数から求めた膨潤時 の比容を用いてこれを修正する方法が提案されている2。 しかしホポエステル瀻維の場合には，单に結晶化度か ら求めた $V$ を用いるか，平衡染着量の比から相対的な $V$ の值が計算されている゙程度で，詳細な研究は行なわれ ていない。

そこで，染色時の収縮率とフェノール水溶液中の収縮 
率とを比較することによって染着領域量を推定する方法 について検討し，興味ある結果を得たので報告する。

\section{2. 実}

\section{験}

\section{1 試 料}

維維；市股のデトロソおよびデトロンT89短瀻維（帝 人株式会社)を、試粹として用いた。テトロンは通常の ポりエチレンテレフタレート(PET) 織維であり, 李た テトトンT 89 は易染性 PET 織維である。試料の主な 性筫は，第1表以示した。

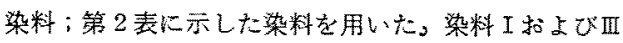
は、市販染料をつセトン特よびペンゼンで数回再結晶す

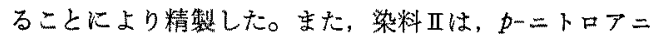
リンとジェチルアニリンから涌常の方法で合度し、アセ トンおよびッンンゼンで精整した。

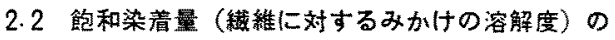 測定}

東业製機製ダンブレット型高正試験染色機を用いた。 試験機の概眵を第1园に示す。染色管に，過剩の染料を 含む $100 \mathrm{cc}$ の染浴（浴比約 $1: 200$ に相当ずる）と，緎 維老入れ，染色温度まで昇温した。次いで，染料の溶解 を十分にするため，その温度で 4 時間放置した後，管を

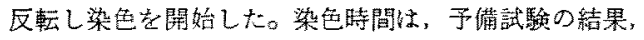
第3表の条件で十分であること確かめた。染色啳は， 還元洗浄を行なって絩維表面の染料を除去し，染着量を 测定した。就，栄着量は，のークロルフェノールに染色 䄳維を溶解し，ての光学密度を測定する方法によって求 bto

\section{3 収䋧率の測定}

牥ではさみやすくするため，瀻維の両端にアルミは
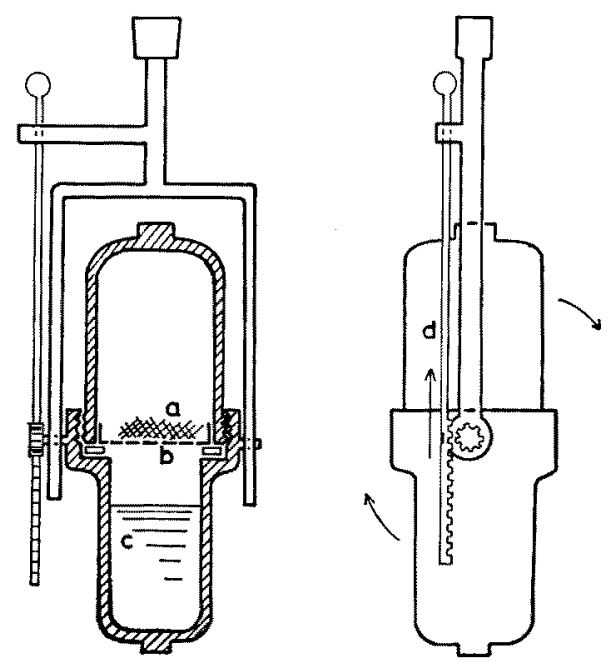

Fig. 1. Apparatus for high pressure dyeing.

$$
\begin{aligned}
& a: \text { Fibre to be dyed } \\
& \text { b: Separating plate } \\
& \text { c: Dye liquor } \\
& \text { d: Lifting lever to tumble dyeing vessel for } \\
& \text { the start of dyeing }
\end{aligned}
$$

Table 3. Dyeing time required for equilibrium

\begin{tabular}{l|r|r|r|r}
\hline & $100^{\circ} \mathrm{C}$ & $110^{\circ} \mathrm{C}$ & $120^{\circ} \mathrm{C}$ & $130^{\circ} \mathrm{C}$ \\
\hline \begin{tabular}{rl|r} 
Tetoron \\
Tetoron T 89
\end{tabular} & $16 \mathrm{hr}$ & $8 \mathrm{hr}$ & $4 \mathrm{hr}$ & $7 \mathrm{hr}$ \\
\hline
\end{tabular}

くを接着し，また，酎水性マークペンで測定長をマーク した。次いで，第 2-a 图の上らに，上端を固定し，300 $\mathrm{mg}$ (数 $0.1 \mathrm{~g} / \mathrm{d}$ K相当, 瀻維の 1 次降伏点は $1 \mathrm{~g} / \mathrm{d}$ 以 上）の特製のばねで下端を荷重する ことにより，原長 $l_{0}$ をせトメータ で貺定した。次いで，第2-b园心示 したよらにフルミはくの部分を取 縮实験用装置のばオ放固定し, 所定 の条件で収縮させた。収縮長りは, 原長已同一の条件で测定し，次式か

Table 2. Properties of purified dyestuffs

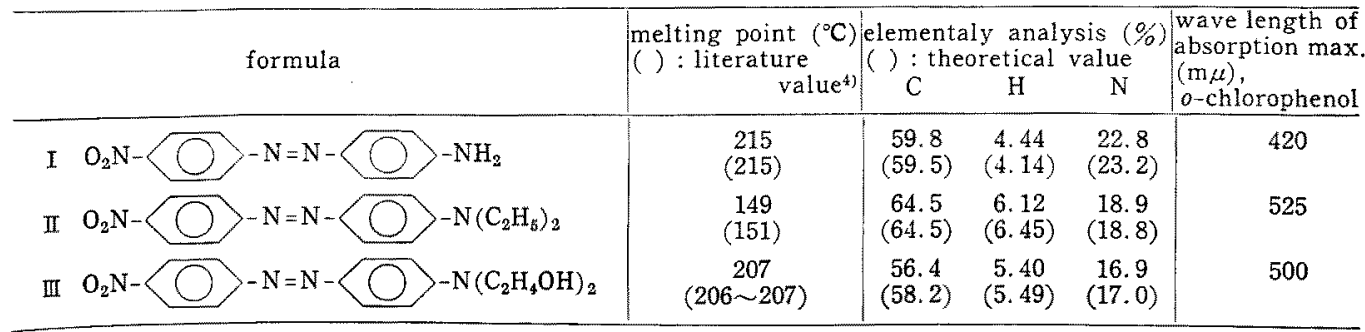



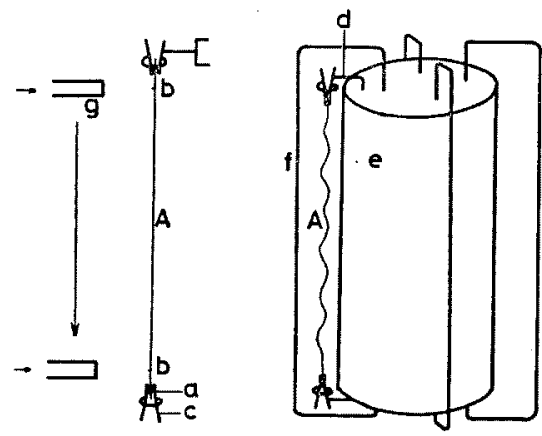

Fig. 2-a. Measurement of fibre length.

A: Fibre to be measured

a: Aluminium thin layer fixed on fibre to make the use of spring easier

$\mathrm{b}$ : Mark for the length to be measured

c: Spring for weighing specially designed (300mg)

g: Reading microscope

Fig. 2-b. Apparatus for contraction

$\mathrm{d}$ : Spring holder (needle)

e: Column made of silicon rubber

$f$ : Protective frame for fibre during experiment

Fig. 2. Meassurement of cotraction

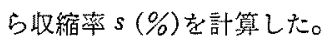

$$
s=\frac{l_{0}-l}{l_{0}} \times 100
$$

なお゙，試料数は 20 とした。

2.4 フェノールの収着等温線

前報的の方法に準じて求めた。

\section{5 密度, 複届折および配向度}

密度は, nーヘプタン, 四塩化炭素による密度勾配管を 用い， $25^{\circ} \mathrm{C}$ で測定した。

複屈折は，ナトリウム光源を用い，偏光顕微鏡の光路 にベレックコンペンセータを挿入して、トリクレジルホ スフェート中で測定した。

結晶配向度 $f_{\mathrm{c}}$ は，(100) 干涉罟上パラトロープ強度 分布曲楾の半価楅 $H^{\circ}$ から，次式により計算した。

$$
f_{c}=\frac{180^{\circ}-H^{\circ}}{180^{\circ}}
$$

また，非晶配向度 $f_{a}$ は

$$
f_{a}=\frac{\Delta n / \Delta n^{\circ}-X f_{c}}{1-X}
$$

から求めた。ここで， $\Delta n, \Delta n^{\circ}$ 和よびXは，それぞれ， 試料の複屈折，完全に結晶化した試料が完全配向時に示 す複屈折括よび次式であらわされる結晶化度である。

$$
X=\frac{d-d_{a}}{d_{c}-d_{a}}
$$

またここで，d，斿および $d_{c}$ は，それぞれ，試椟，非
晶礼よび結晶の密度である。 $\Delta n^{\circ} ， d_{a}$ お゙よび $d_{c}$ として それぞれ，0.216无，1.335 和よび 1.455 を用いた。

\section{3. 結果および考察}

\section{1 染着に関与する高分子の重量分率（染着領域量） の推定}

\section{1 .1 染着モデル}

イオン染料の水溶液から染色する場合には，織維内部 に染料溶液で满たされた種々の大きさの間げきが存在す るものと仮定し，そして染料は間げきの表面で吸着され るものと考えられている7゙,8。しかしここのモデルは， 吸水量か゚極端に低いポリエステル緎維の, しかも非イオ ン性染料による染色の場合にるあてはまるかどらかは寲 問である。

たとえば, $100 \% \mathrm{RH}$ 中における收着水の容積より， 飽和染着時の染料の容積のほうが大きくなることを計算 した例もみられる9う。，分散染料は蒸気相からも染 着され，多くの場合染着等温線が直線であること，繊維 中で染料は単分子の状態で存在すると考えられること ${ }^{10}$

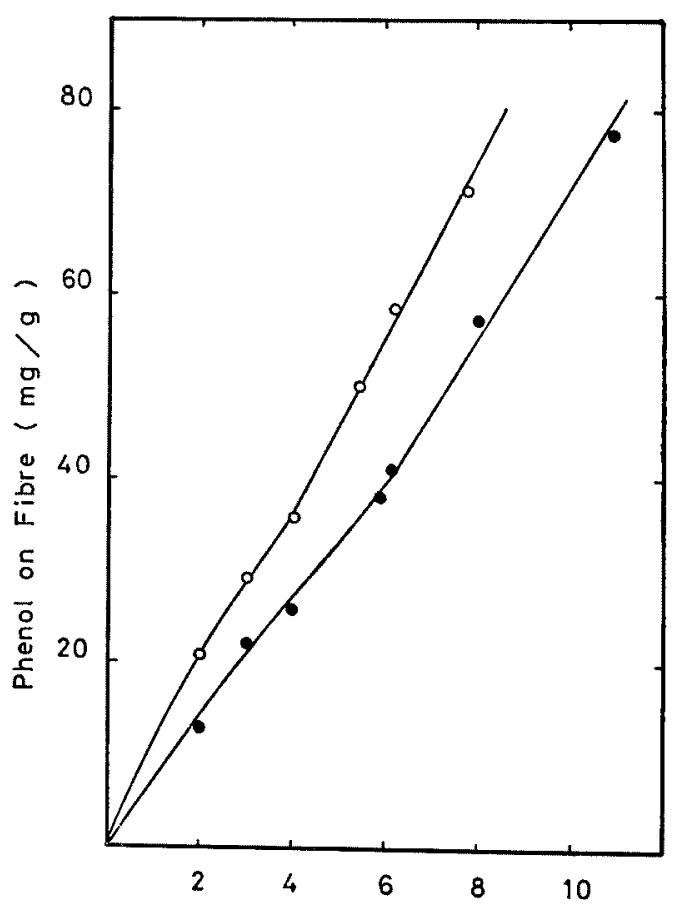

Phenol in Solution (mole fraction $\times 10^{3}$ )

Fig. 3. Absorption isotherms of phenol on Tetoron and Tetoron $\mathrm{T} 89$.

: Tetoron

: Tetoron $\mathrm{T} 89$ 


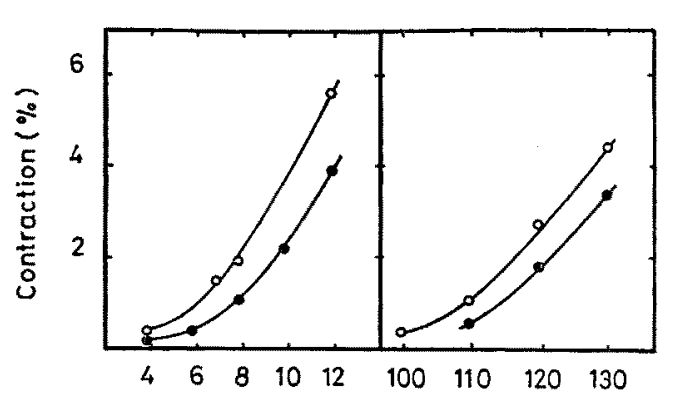

Phenol in Solution Temperature of (mole fraction $\times 10^{3}$ ) Dyeing $\left({ }^{\circ} \mathrm{c}\right.$ )

Fig. 4. Contractions on dyeing and phenol absorption

: Tetoron

$\mathrm{O}:$ Tetoron $\mathrm{T} 89$

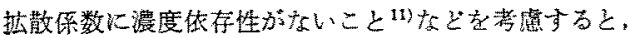
染リエステル織維の分散染料に上る染色は，高分子と染 料分子とが何らかの形で混合することによって行なわれ るものと芳充るのが妥当である。

そこで, 非対称理想基準䒺を用い，緎維中の染数の化 学ポテンシャルを次式であらわすことにする。

$$
\mu_{f}=\mu_{f} *+R T \ln r_{f} m_{f} \frac{1}{V^{*}}
$$

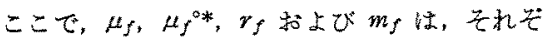
れ，䋐維中の染料の化学ポテンシャル，繊維中 の染料の標準状熊に蚂ける化学ポテンシャル，

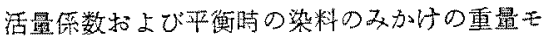

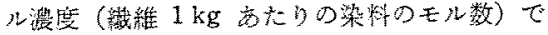
古り，V*は，轵維 $1 \mathrm{~kg}$ 古たりの，染料分子 との泥合に用いられる高分子の重量で岕る。

3.1 .2 染色かよびフェノール取着封の取縮 率之染着湎域量の推定

$70^{\circ} \mathrm{C}$ に和けるフェノ一ルの收着等温線大第

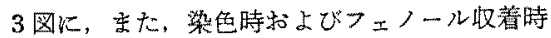
の収縮率至第4图に示した。染色時の収縮率に は染料化よる盖はみられなかった。亲た、フェ ノ一ルの収着等温線の形から判断子ると, 取着 領域量はフェノールの漊度ととすに增大してい るがロ，これ奶応した形で、フェノール取着 時の収縮率も增大した。したがって，染色の場 合以る，染着攽域量と染色時の收縮率との間に は, 何らかの対空のあることが期待される。そ

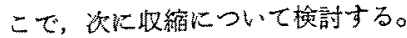

延伸䋐維は分子鋝が正ばされた状態で分子鎖 間の2次結合に上り固定されているが(もらろ んこのながは，䡚々の安定度の凝集状態が含

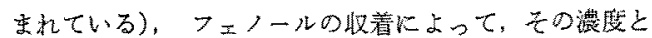
温度に対応する安定度以下の凝焦状態が非晶化され分子 鎖間の 2 次結合が切断されると市，鎖状分子はコイルし てエントロピー的に安定な状態へ梨行しよらとするため

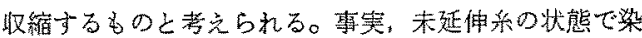

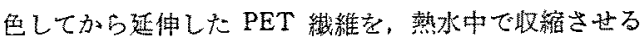
場合，結鼠配向度は变わらず，2色性比だ方が低下する

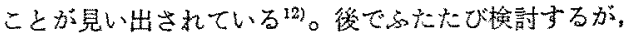
ここで間題にする収縮については，この機㮖だけを妨え 万。

いま，䄳維の長さは，配向が緩和されだ非晶領城と乙 れ以外の領域の、瀻維軸方向の長さの和であらわされる

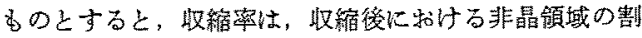
合と，その領域の収縮前の配向度とによって，主として 定まるものと考光られる。そこで，式（1）であらわさ れる非晶配向度 $f_{a}$ 辛翼なる試料机つて，フェノール 水嚓液中心扣ける収縮率之，フェノールの收着量加前

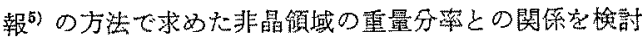
した。結果を第 5 图に水した。第 5 因て，収縮率は，収 縮後の非晶領域の重量分率とともに增大し, また, 収縮

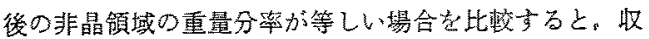
縮前の $f_{a}$ が大なる試料はど大なる収縮率を示した。こ れらの結果は，上に示した収縮機構と矛盾しない。

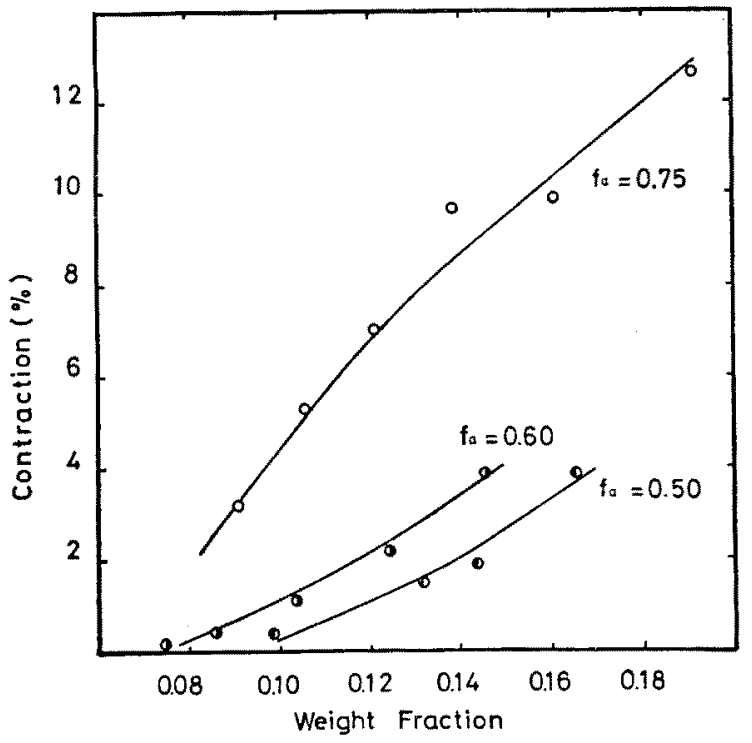

Fig. ${ }^{5}$. Contraction as a function of weight fraction of absorption region on phenol absorption

$O$ : untreated filament described in privious paper

D: Tetoron $T 89$

Q : Tetoron 
一方, 染色㭙の収䈹率についても，染色温度が高くな るにしたがって，上り安定な凝集状態の分子鎖間の 2 次 結合が切断されるため，収縮深が增大するものと考党ら れる。同一織維は，ある一定の㠜集状態之配向度の分布 をもっているから，收縮機構が同一である限り，收縮後 の非晶領域の重量分率之收樎率とは $1: 1$ に対応する。 したがって, 染色した後の非晶領域の重量分率は, 染色 時の収縮率とフェノール収着時の収縮率とを比較するこ とにより,フェノールの収着量から前報ら方法で推定 できる。また， $V *$ は非晶領域の重量分率汇相当するも のとみなされるからここ示した方法でV*を求める ことができる。

この方法で求めた，テトロンおよびテトロンT 89 の $V *$ の值を第 4 表に示した。なお，表の值は第 4 図の収 縮率と第 3 因の収着等温線とから計算した。

ところで, Dismore と Stattonは, ナイトン 66 延伯

Table 4. The fraction of dye absorption region (wt \%)

\begin{tabular}{l|r|r|r|r}
\begin{tabular}{l|r|r} 
Dyeing temperature \\
Fibre
\end{tabular} & 100 & 110 & 120 & 130 \\
\hline $\begin{array}{l}\text { Tetoron } \\
\text { Tetron } \Upsilon \mathrm{C} 89\end{array}$ & 10.0 & 12.5 & 11.7 & 13.8 \\
\hline
\end{tabular}

系の熱収縮について，配向緩和以外に，収縮に対する Chain folding の笴与が存在することを見い出してい

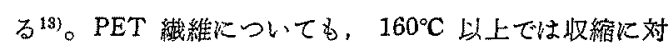
するChain folding の寄与を考虑しなければならないる のと思われるが14)，いま問題にしているのは $130^{\circ} \mathrm{C}$ 以下 の温度であるから，収縮はここで仮定したよらな配向 䌅和の奇与たけけによるるのと考えて上いであるう。

\section{2 飽和染着量と染着領域量の検討}

テトロン和よびテトロンT 89 K対する， 3 種の分散 染料の及かけの溶解度技上び第 4 表の $V^{*}$ で補正した真 の溶解度を，それぞれ，第6四に示した。みかけの溶解 度は，いずれの染料についても、テトロンよりテトロン T 89 のほらが大であったが, 補正した真の溶解度は， ほぼ等しくなった。

飽和溶解度が測定される条件では, 固体染料, 水に溶 解した染料扣よび染着した染料の間には，平衡関係が存 在するから，その化学ポテンシャルは等しい。そこで, 固体染料の分子ェンタルピーんを標準にとり，PETに

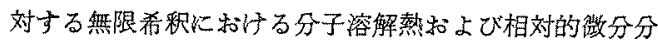
子ェンタルピーを，それぞれ，ll扰よびしとすると

$$
\begin{aligned}
& l_{s}=h_{f}-h \\
& l=h_{f}-h_{f}^{\circ}
\end{aligned}
$$

ここで，hf扎よび $h_{f}^{\circ}$ は，それでれ，瀻維中括ける

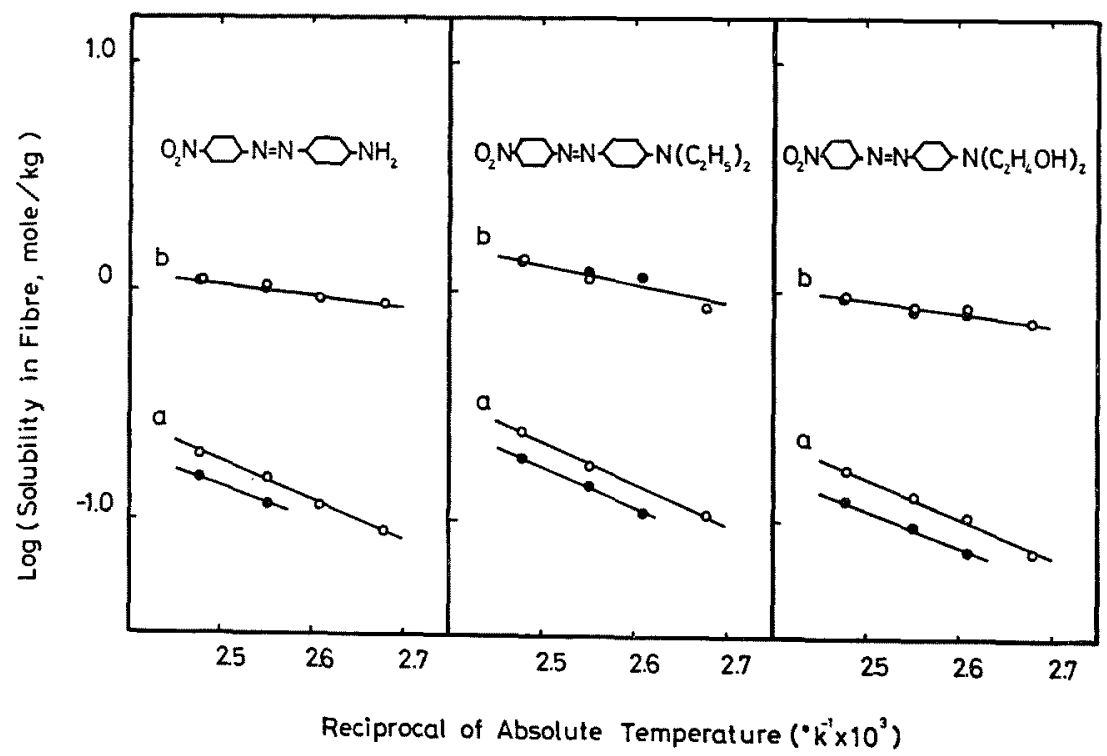

Fig. 6. Log (solubility in fibre) vs. reciprocal of absolute temperature

: Tetoron

a : uncorrected(apparent solubilities)

O.. Tetoron T 89

$b$ : corrected by fraction of dye absorption region (true solubilities) 
染料の微分分子エンタルピー扣上び媫限希积における微 分分子ェンタルビーである。また，溶解度の温度变化は

$$
\frac{\partial \ln \left(m_{f} / V^{*}\right)}{\partial T}=\frac{l_{s}+l}{R T^{2}}
$$

で与えられる。

いま，ある染料の，テトロソとテトロンT 89 に刘可 る溶解度を比較する場合，雨緎維はともに PET である から，ls+l同一とみなすのが妥当であろう。したが って，第6図より，ここで提案した万法によって求めた $V^{*}$ でみかけの溶解度を補正すると, 真の溶解度とその 温度变化が等しくなるといら妥当な結果が得られること が明らかとなった。このことはみかだ迹にすれば、こ こで提案した $V *$ の妥当性を立証するものとみなされ る。

\section{文献}

1）たとえば，黑木宣彦; 染色理論化学 (梖書店)，p. 92 (1966)

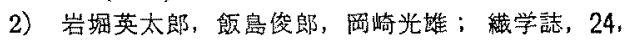
300 (1668)

3) W.McDowell, R.Weingarten ; Melliand Textilber., 50, 814 (1969)

4) C. L. Bird; J. Soc. Dyers Colourists, 70, 68
(1954)

5）要多村一夫, 小林重信, 吉田善一; 䋐学誌投稿中 (前報) No. 2976

6）栗山将，富板和夫，白樫拀；螨学誌，20，431 (1964)

7) たとえば

H. A. Standing, J. O. Warwicker, H. E. Willis ; J. Textile Inst., 38, T 335 (1947)

J. Crak; J.Soc. Dyers Colourists, $63 \quad 412(1947)$ 66, $360(1950)$

J. 0. Warwicker; J. Polymer Sci., A 13105 (1963)

8) M. E. Hopper, R. McGregor; J. Soc. Dyers Colourists, 86116 (1970)

9) 鶴岡信三, 小島弘; 馀学誌, 24, 35 (1968)

10) K. Hoffman, KW. McDowell, R. Weingarten : J. Soc. Dyers Colourists, 84, 306 (1968) ; 85 , 418 (1969)

11）たとえば，関戸実，小彁弘；緎学誌，21，644 (1965)

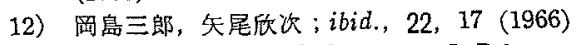

13) P.F.Dismore, W.O. Statton; J. Polymer Sci., C, No. 13, 133 (1966)

14）上田伸夫，温品恭彦；高化，21，337（1964） 